\title{
Diazocinones: Synthesis and Conformational Analysis
}

Lori I. Robins, ${ }^{\dagger}$ Richard D. Carpenter, ${ }^{\dagger}$ James C. Fettinger, $^{\dagger}$ Makhluf J. Haddadin,,$^{\ddagger}$ Dino S. Tinti, ${ }^{\dagger} *$ and Mark J. Kurth ${ }^{\dagger} *$

${ }^{\dagger}$ Department of Chemistry, One Shields Avenue, University of California, Davis, CA 95616

Department of Chemistry, American University of Beirut, Beirut, Lebanon

* mjkurth@ucdavis.edu; dstinti@ucdavis.edu

Supporting Information Table of Contents

Detailed experimental procedures for 9, 10b, 3b, 8a-d, 2a-d, 1b-h........................S2-S9

${ }^{1} \mathrm{H}-\mathrm{NMR},{ }^{13} \mathrm{C}-\mathrm{NMR}$, and HPLC data for 1a-h, 3a, 10a ........................................ 10-S19

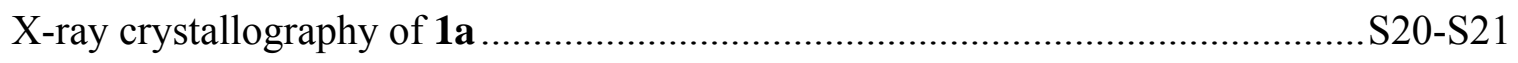

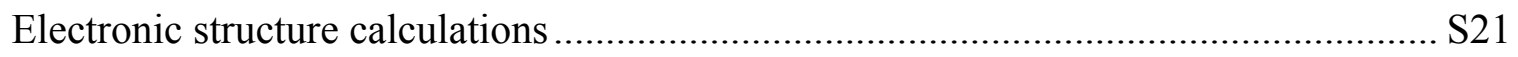

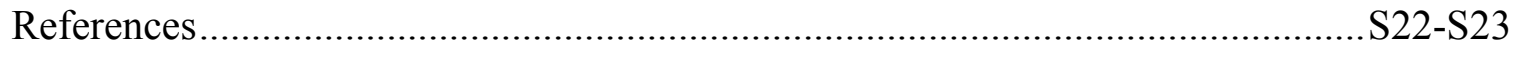




\section{Experimental Section}

General Procedures. All chemicals were purchased from commercial suppliers and used without further purification. Analytical TLC was carried out on pre-coated plates (silica gel 60, F254) and visualized with UV light. Flash chromatography was performed with silica gel 60 (230-400 mesh). NMR spectra $\left({ }^{1} \mathrm{H}\right.$ at $300 \mathrm{MHz}, 400 \mathrm{MHz},{ }^{13} \mathrm{C}$ at $100 \mathrm{MHz}$ ) were recorded in $\mathrm{CDCl}_{3}$ and $\mathrm{DMSO}-\mathrm{d}_{6}$ as solvents and chemical shifts are expressed in parts per million related to internal TMS. The specification of the LC/MS are as follows: electrospray (+) ionization, mass range 200-900 Da, 20-V cone voltage, and XTerra MS $\mathrm{C}_{18}$ column $(2.1 \mathrm{~mm} \times 50 \mathrm{~mm} \times 3.5 \mu \mathrm{m})$. $\mathrm{CC}$ refers to column chromatography. Concentration refers to rotoevaporation.

cis-3-Phenylsulfonyl-3-vinylcyclobutanol 9. Phenyl allyl sulfone (6.0 g, 32.9 mmol) was dissolved in THF at $0{ }^{\circ} \mathrm{C}$, followed by the dropwise addition of $n$-BuLi $(43 \mathrm{~mL}, 68$ mmol, 1.6 M) with stirring for 1 hour. The yellow solution was then treated with epichlorohydrin (3.99 g, $42.77 \mathrm{mmol}$ ), and the mixture warmed to room temperature for 12 hours. As a work up procedure, the solution was washed with water, followed by the extraction of the THF layer. This layer was washed with brine, dried with $\mathrm{MgSO}_{4}$, vacuum filtered, and concentrated to give a yellow oil (5.5 g, 70\%): ${ }^{1} \mathrm{H}$ NMR $\delta 2.54-2.8$ $(\mathrm{m}, 2 \mathrm{H}, J=6.9 \mathrm{~Hz}), 2.78-2.82(\mathrm{~m}, 2 \mathrm{H}, J=6.9 \mathrm{~Hz}), 4.16(\mathrm{t}, 1 \mathrm{H}, J-6.9 \mathrm{~Hz}), 5.03(\mathrm{~d}, 1 \mathrm{H}, J$ $=17.1 \mathrm{~Hz}), 5.32(\mathrm{~d}, 1 \mathrm{H}, J=10.5 \mathrm{~Hz}), 5.93(\mathrm{dd}, 1 \mathrm{H}, J=17.1,10.5 \mathrm{~Hz}), 7.48-7.75(\mathrm{~m}$, 4H). The ${ }^{13} \mathrm{C}$ and IR fit the previously reported data. ${ }^{1}$

\section{5-(1-Benzenesulfonyl-3-hydroxycyclobutyl)-3-(4-methoxyphenyl)-4,5-}

dihydroisoxazole (10b). 3-benzenesulfonyl-3-vinyl-cyclobutanol (9) (1.5g, 6.25mmol) and 4-Methoxy-benzaldehyde oxime (4 equiv., 3.77g, 25mmol) were dissolved in $\mathrm{CH}_{2} \mathrm{Cl}_{2}$ 
(45 ml). Aqueous $\mathrm{NaOCl}$ (4 equiv., $1.85 \mathrm{~g}, 25 \mathrm{mmol}$ ) was added dropwise at $0^{\circ} \mathrm{C}$. The mixture was allowed to warm to room temperature and stirred overnight. The mixture was then extracted with $\mathrm{CH}_{2} \mathrm{Cl}_{2}$, dried over $\mathrm{MgSO}_{4}$, and concentrated. Crystallization with $\mathrm{CH}_{2} \mathrm{Cl}_{2}$ and hexanes gave pure compound $10 \mathrm{~b}(1.1 \mathrm{~g}, 78 \%)$ as a white solid: ${ }^{1} \mathrm{H}$ NMR $\delta$ 2.57-2.65 (m, 2H), $3.40(\mathrm{~d}, 2 \mathrm{H}, J=9.6 \mathrm{~Hz}), 3.86(\mathrm{~s}, 3 \mathrm{H}), 4.40(\mathrm{~m}, 1 \mathrm{H}), 4.63(\mathrm{t}$, $1 \mathrm{H}, J=9.6 \mathrm{~Hz}), 6.91(\mathrm{~d}, 2 \mathrm{H}, J=8.7 \mathrm{~Hz}), 7.57(\mathrm{~d}, 2 \mathrm{H}, J=8.7 \mathrm{~Hz}), 7.60-7.89(\mathrm{~m}, 5 \mathrm{H})$; The ${ }^{13} \mathrm{C}$, and IR data is consistent with previous literature values. ${ }^{1}$

3-(4-Methoxyphenyl)-5-(3-oxocyclobutyl)isoxazole (3b). Compound 10b (.5g, 1.3 mmol) was oxidized via regular Swern Oxidation procedures (oxalyl chloride (1.3 equiv.), DMSO (2.5 equiv.), Et3N (5 equiv.) in $\mathrm{CH}_{2} \mathrm{Cl}_{2}$. The crude product was purified by CC (hexanes:ethyl acetate, 7:3) to give (10b) $(.27 \mathrm{~g}, 87 \%)$ as an off-white solid. ${ }^{1} \mathrm{H}$ NMR $\delta 3.37-3.57(\mathrm{~m}, 4 \mathrm{H}), 3.82(\mathrm{~s}, 3 \mathrm{H}) 6.36(\mathrm{~s}, 1 \mathrm{H}), 6.94(\mathrm{~d}, 2 \mathrm{H}, J=8.4 \mathrm{~Hz}), 7.71(\mathrm{~d}, 2 \mathrm{H}$, $J=8.4 \mathrm{~Hz}) ;{ }^{13} \mathrm{C}$, and IR data is consistent with previous literature values. ${ }^{1}$

3,6-Diphenyl-1,4-dihydro-[1,2,4,5]tetrazine 8a. In a $50 \mathrm{~mL}$ round bottom flask, benzonitrile $(8.0 \mathrm{~mL}, 77.6 \mathrm{mmol})$ was dissolved in $15 \mathrm{~mL}$ of absolute ethanol. Hydrazine ( $3.65 \mathrm{~mL}, 0.116 \mathrm{~mol})$ and sulfur $(1.55 \mathrm{~g})$ were quickly added, and the solution refluxed for 3 hours with stirring. The remaining orange cake was solidified further in an ice bath. The solid was pulverized, vacuum filtered, and washed with cold ethanol $(2 \times 10 \mathrm{~mL})$ giving the crude dihydro tetrazine $(15.8 \mathrm{~g}, 86 \%)$.

3,6-Diphenyl-[1,2,4,5]tetrazine 2a. The crude flaky orange solid of $\mathbf{8 a}(991 \mathrm{mg})$ was then placed in a $50 \mathrm{~mL}$ beaker and dissolved in acetic acid $(15 \mathrm{~mL})$ at room temperature with stirring. An aqueous solution of $\mathrm{NaNO}_{2}(15 \mathrm{~mL})$ was added to the solution at $0{ }^{\circ} \mathrm{C}$. The immediate purple cloudiness signifies the completion of the reaction, as well as the 
evolution of brown nitric oxide gas. Vacuum filtration and washing with methanol $(2 \mathrm{x}$ $10 \mathrm{~mL}$ ) gave the deep purple tetrazine (687 mg, 69\%): ${ }^{1} \mathrm{H}$ NMR 7.42-7.68 (t, 3H), 8.02 $(\mathrm{d}, 1 \mathrm{H}), 8.62(\mathrm{~d}, 1 \mathrm{H})$.

3,6-Di-p-tolyl-1,4-dihydro-[1,2,4,5]tetrazine $8 \mathrm{~b}$. In a $50 \mathrm{~mL}$ round bottom flask, $p$ toluene-nitrile $(7.71 \mathrm{~g})$ was dissolved in $15 \mathrm{~mL}$ of absolute ethanol. Hydrazine $(2.20 \mathrm{~mL}$, $69.9 \mathrm{mmol})$ and sulfur $(0.932 \mathrm{~g})$ were quickly added, and the solution refluxed for 3 hours with stirring. The reaction was stopped and the yellow-orange slurry was placed in an ice bath for further solidification. The solution was then subjected to vacuum filtration and washed with cold ethanol $(2 \times 10 \mathrm{~mL})$ giving the crude dihydro tetrazine (8.92 g. $80 \%)$.

3,6-Di-p-tolyl-[1,2,4,5]tetrazine 2b. The yellow-orange solid of $\mathbf{8 b}(3.2 \mathrm{~g})$ was then placed in a $50 \mathrm{~mL}$ beaker and dissolved in acetic acid $(20 \mathrm{~mL})$ at room temperature with stirring. An aqueous solution of $\mathrm{NaNO}_{2}(20 \mathrm{~mL})$ was added to the solution at $0{ }^{\circ} \mathrm{C}$. The immediate purple pre-cipitate signifies the completion of the reaction, as well as the evolution of brown nitric oxide gas. Vacuum filtration and washing with methanol $(2 \mathrm{x}$ $10 \mathrm{~mL}$ ) gave the dark purple tetrazine (3.19 g, 99\%): ${ }^{1} \mathrm{H}$ NMR 2.38 (s, 3H), 2.49 (s, 3H), $7.39(\mathrm{~d}, 2 \mathrm{H}), 7.90(\mathrm{~s}, 1 \mathrm{H}), 8.57(\mathrm{~s}, 1 \mathrm{H})$.

3,6-Bis-(4-chloro-phenyl)-1,4-dihydro-[1,2,4,5]tetrazine 8c. In a $50 \mathrm{~mL}$ round bottom flask, 4-chlorobenzonitrile $(4.0 \mathrm{~g})$ was dissolved in $15 \mathrm{~mL}$ of absolute ethanol. Hydrazine $(1.37 \mathrm{~mL}, 0.214 \mathrm{~mol})$ and sulfur $(0.582 \mathrm{~g})$ were quickly added, and the solution refluxed for 3 hours with stirring. The orange cake was solidified further in an ice bath. The solid was grinded, vacuum filtered, and washed with cold ethanol $(2 \times 10$ $\mathrm{mL}$ ) giving the crude dihydro tetrazine $(7.37 \mathrm{~g}, 90 \%)$. 
3,6-Bis-(4-chloro-phenyl)-[1,2,4,5]tetrazine 2c. The orange solid of 8c $(800 \mathrm{mg})$ was then placed in a $50 \mathrm{~mL}$ beaker and dissolved in acetic acid $(15 \mathrm{~mL})$ at room temperature with stirring. An aqueous solution of $\mathrm{NaNO}_{2}(15 \mathrm{~mL})$ was added to the solution at $0{ }^{\circ} \mathrm{C}$. The immediate purple cloudiness signifies the completion of the reaction, as well as the evolution of brown nitric oxide gas. Vacuum filtration and washing with methanol $(2 \mathrm{x}$ $10 \mathrm{~mL}$ ) gave the dark purple tetrazine $(0.77 \mathrm{~g}, 97 \%):{ }^{1} \mathrm{H}$ NMR $7.52-7.63(\mathrm{~d}, 2 \mathrm{H}), 7.98(\mathrm{~d}$, $1 \mathrm{H}), 8.62(\mathrm{~s}, 1 \mathrm{H})$.

3,6-Bis-(4-bromo-phenyl)-1,4-dihydro-[1,2,4,5]tetrazine 8d. In a $50 \mathrm{~mL}$ round bottom flask, 4-bromobenzonitrile $(6.0 \mathrm{~g})$ was dissolved in $15 \mathrm{~mL}$ of absolute ethanol. Hydrazine $(1.55 \mathrm{~mL}, 49.5 \mathrm{mmol})$ and sulfur $(0.659 \mathrm{~g})$ were quickly added, and the solution refluxed for 3 hours with stirring. The reaction was stopped and the orange slurry was placed in an ice bath for further solidification. The solution was then subjected to vacuum filtration and washed with cold ethanol $(2 \times 10 \mathrm{~mL})$ giving the crude dihydro tetrazine (11.4 g 88\%).

3,6-Bis-(4-bromo-phenyl)-[1,2,4,5]tetrazine 2d. The orange solid of $\mathbf{8 d}(2.5 \mathrm{~g})$ was then placed in a $50 \mathrm{~mL}$ beaker and dissolved in acetic acid $(20 \mathrm{~mL})$ at room temperature with stirring. An aqueous solution of $\mathrm{NaNO}_{2}(20 \mathrm{~mL})$ was added to the solution at $0{ }^{\circ} \mathrm{C}$. The immediate purple precipitate signifies the completion of the reaction, as well as the evolution of brown nitric oxide gas. Vacuum filtration and washing with methanol $(2 \mathrm{x}$ $10 \mathrm{~mL}$ ) gave the dark purple tetrazine (2.25 g, 90\%): ${ }^{1} \mathrm{H}$ NMR $7.35(\mathrm{~d}, 1 \mathrm{H}), 7.38(\mathrm{~d}, 1 \mathrm{H})$, $7.46(\mathrm{~d}, 1 \mathrm{H}), 7.50(\mathrm{~d}, 1 \mathrm{H})$.

General procedure for synthesis of 1,2 Diazocinones. The respective cyclobutanone (3a-b) and the tetrazine (2a-d) were dissolved in $20 \mathrm{~mL}$ of THF. To this solution $5 \%$ 
$\mathrm{KOH} / \mathrm{MeOH}$ was added dropwise at room temperature. The solution was allowed to stir for 4 hours and then concentrated. The crude material was then taken up with EtOAc, washed with water followed by brine. The organic layer was dried over $\mathrm{MgSO}_{4}$, filtered, concentrated, and chromatographed to afford the 1,2 diazocinone.

\section{3,8-Bis-(4-chlorophenyl)-6-(3-phenylisoxazol-5-yl)-6,7-dihydro-5H-[1,2]diazocin-4-}

one (1b). Following the general 1,2 diazocinone synthesis, cyclobutanone 3a and tetrazine $2 \mathbf{b}$ gave $\mathbf{1 b}(52 \mathrm{mg}, 46 \%)$ : Mp $178-179^{\circ} \mathrm{C}$. IR (neat) $1714,1599,1428,1252 ;{ }^{1} \mathrm{H}$ NMR $\delta$ 2.84-2.88 (dd, $1 \mathrm{H}, J=4.2,11.3 \mathrm{~Hz}), 2.95-2.97(\mathrm{dd}, 1 \mathrm{H}, J=3.9,17.8 \mathrm{~Hz}), 3.02-$ $3.08(\mathrm{dd}, 1 \mathrm{H}, J=9.56,13.08 \mathrm{~Hz}), 3.14-3.20(\mathrm{dd}, 1 \mathrm{H}, 10.9,13.9 \mathrm{~Hz}), 3.35-3.39(\mathrm{dd}, 1 \mathrm{H}$, 5.27, 9.96Hz), 3.42-3.46 (dd, 1H, 3.91, 13.86Hz), 3.82-3.93 (m, 1H), $6.30(\mathrm{~s}, 1 \mathrm{H}), 6.36$ (s, 1H), 7.30-7.32 (dd, 2H, 2.04, 6.84Hz), 7.45-7.47 (m, 5H), 7.59-7.61 (dd, 2H, 2.0, 6.8Hz), 7.68-7.71 (m, 3H), 7.81-7.83 (d, $1 \mathrm{H}, 8.6 \mathrm{~Hz}) ;{ }^{13} \mathrm{C}$ NMR $\delta 202.7,172.8,162.8$, $152.4,149.4,137.7,137.1,133.2,130.6,129.6,129.5,129.2,128.7,128.5,128.4,126.9$, 99.7, 45.1, 31.0, 30.9. ESI MS (M+H) $\mathrm{m} / \mathrm{z}$ calcd, 487.09; found, 488.09. HRMS (ESI) for $\mathrm{C}_{27} \mathrm{H}_{20} \mathrm{Cl}_{2} \mathrm{~N}_{3} \mathrm{O}_{2}$ calcd $488.0927\left(\mathrm{M}+\mathrm{H}^{+}\right)$, obsd 488.0904.

\section{3,8-Bis-(4-bromophenyl)-6-[3-(phenyl)isoxazol-5-yl]-6,7-dihydro-5H-[1,2]diazocin-}

4-one (1c). Following the general 1,2 diazocinone synthesis, cyclobutanone 3a and tetrazine 2c gave 1c (63mg, 38\%): Mp 200-201 ${ }^{\circ} \mathrm{C}$; IR (neat) 1697, 1587, 1441, 1394; ${ }^{1} \mathrm{H}$ NMR $\delta$ 2.83-2.87 (dd, $1 \mathrm{H}, 6.64,11.32 \mathrm{~Hz}), 2.95-3.00(\mathrm{dd}, 1 \mathrm{H}, 2.0,15.8 \mathrm{~Hz}), 3.01-3.07$ (dd, 1H, 9.6, 13.3Hz), 3.13-3.19 (dd, 1H, 10.35, 12.6Hz), 3.23-3.45 (m, 2H), $6.30(\mathrm{~s}, 1 \mathrm{H})$, $6.35(\mathrm{~s}, 1 \mathrm{H}), 7.46-7.48(\mathrm{~m}, 5 \mathrm{H}), 7.51-7.54(\mathrm{~d}, 2 \mathrm{H}, 7.8), 7.56-7.59$ (dd, 2H, 5.1, 6.4Hz), 7.68-7.71 (m, 2H), 7.74-7.76 (d, 2H, 8.78); ${ }^{13} \mathrm{C}$ NMR $\delta 202.5,202.0,173.2,173.8,162.8$, $151.4,151.4,149.5,135.3,133.7,132.7,132.6,132.5,132.1,130.6,130.3,129.9,129.5$, 
129.2, 129.1, 128.9, 128.8, 128.7, 128.6, 127.0, 126.9, 126.2, 126.0, 125.6, 100.0, 99.7, 46.1, 45.2, 31.8, 31.0, 30.9, 30.1. ESI MS $(\mathrm{M}+\mathrm{H}) \mathrm{m} / \mathrm{z}$ calcd, 574.98; found, 575.79. HRMS (ESI) for $\mathrm{C}_{27} \mathrm{H}_{20} \mathrm{Br}_{2} \mathrm{~N}_{3} \mathrm{O}_{2}$ calcd $575.9917\left(\mathrm{M}+\mathrm{H}^{+}\right)$, obsd 575.9893.

6-(3-Phenylisoxazol-5-yl)-3,8-di-p-tolyl-6,7-dihydro-5H-[1,2]diazocin-4-one (1d).

Following the general 1,2 diazocinone synthesis cyclobutanone 3a and tetrazine 2d gave 1d (41mg, 40\%): Mp 138-139 ${ }^{\circ} \mathrm{C}$. IR (neat) 1712, 1611, 1527, 1433, 1251; ${ }^{1} \mathrm{H}$ NMR $\delta$ $2.37(\mathrm{~s}, 3 \mathrm{H}), 2.40(\mathrm{~s}, 3 \mathrm{H}) 2.81-2.87(\mathrm{dd}, 1 \mathrm{H}, 4.7,12.4 \mathrm{~Hz}), 3.01-3.09(\mathrm{dd}, 1 \mathrm{H}, 10.2$, 12.6Hz), 3.13-3.22 (dd, $1 \mathrm{H}, 10.5,12.9 \mathrm{~Hz}), 3.18-3.19(\mathrm{~m}, 1 \mathrm{H}), 3.42-3.46(\mathrm{dd}, 1 \mathrm{H}, 2.8$, 12.9Hz), $6.35(\mathrm{~s}, 1 \mathrm{H}), 7.22-7.31(\mathrm{~m}, 4 \mathrm{H}), 7.43-7.45(\mathrm{~m}, 2 \mathrm{H}), 7.55-7.58(\mathrm{~d}, 2 \mathrm{H}, 8.3 \mathrm{~Hz})$, 7.69-7.70(d, $1 \mathrm{H}, 3.85), 7.71-7.72(\mathrm{~d}, 1 \mathrm{H}, 2.75), 7.77-7.79(\mathrm{~d}, 2 \mathrm{H}, 8.25) ;{ }^{13} \mathrm{C}$ NMR $\delta$ 21.6, $21.7,31.1,45.2,99.5,126.9,127.1,127.3,128.0,128.5,129.2,129.9,130.0,130.1$, 130.5, 132.3, 141.1, 141.9, 150.5, 173.5, 204.0. ESI MS $(\mathrm{M}+\mathrm{H}) \mathrm{m} / \mathrm{z}$ calcd, 447.19; found, 448.13. HRMS (ESI) for $\mathrm{C}_{29} \mathrm{H}_{26} \mathrm{~N}_{3} \mathrm{O}_{2}$ calcd 448.2020 $\left(\mathrm{M}+\mathrm{H}^{+}\right)$, obsd 448.2020.

\section{6-[3-(4-Methoxyphenyl)isoxazol-5-yl]-3,8-diphenyl-6,7-dihydro-5H-[1,2]diazocin-}

4-one (1e). Following the general 1,2 diazocinone synthesis cyclobutanone $3 \mathbf{b}$ and tetrazine 2a gave 1e (52mg, 51\%) as a white solid. Mp 127-129 ${ }^{\circ} \mathrm{C}$. IR(neat) 1712,1611 , $1527,1429,1293 ;{ }^{1} \mathrm{H}$ NMR $\delta 2.85-2.90(\mathrm{dd}, 1 \mathrm{H}, J=4.8,12.8 \mathrm{~Hz}), 3.03-3.09(\mathrm{dd}, 1 \mathrm{H}, J=$ $10.0,12.4 \mathrm{~Hz}), 3.16-3.22(\mathrm{dd}, 1 \mathrm{H}, J=10.8,13.2 \mathrm{~Hz}), 3.26-3.30(\mathrm{~m}, 1 \mathrm{H}), 3.45-3.49$ (dd, $1 \mathrm{H}, J=1.6,12.4 \mathrm{~Hz}), 3.85(\mathrm{~s}, 3 \mathrm{H}), 6.32(\mathrm{~d}, 1 \mathrm{H}, J=1.0), 6.94-6.95(\mathrm{dd}, 2 \mathrm{H}, J=2,6.8 \mathrm{~Hz})$, 7.44-7.47 (m, 6H), 7.64-7.70 (m, 4H), 7.88-7.90 (m, 2H); ${ }^{13} \mathrm{C}$ NMR $\delta$ 203.9, 173.1, $162.5,161.5,153.7,150.5,135.1,131.5,131.2,130.9,129.4,129.3,128.5,127.6,127.3$, 121.3, 114.7, 99.4, 55.7, 45.2, 31.3, 31.2. ESI MS $(\mathrm{M}+\mathrm{H}) \mathrm{m} / \mathrm{z}$ calcd, 449.17; found, 450.02. HRMS (ESI) for $\mathrm{C}_{28} \mathrm{H}_{24} \mathrm{~N}_{3} \mathrm{O}_{3}$ calcd $450.1812\left(\mathrm{M}+\mathrm{H}^{+}\right)$, obsd 450.1834 . 


\section{3,8-Bis-(4-chlorophenyl)-6-[3-(4-methoxyphenyl)isoxazol-5-yl]-6,7-dihydro-5H-}

[1,2]diazocin-4-one (1f). Following the general 1,2 diazocinone synthesis cyclobutanone 3b and tetrazine $2 \mathbf{b}$ gave 1f (52mg, $46 \%)$ : Mp $160-162^{\circ} \mathrm{C}$. IR (neat) 1711, 1613, 1529, 1429, $1252 ;{ }^{1} \mathrm{H}$ NMR $\delta 2.78-2.83(\mathrm{dd}, 1 \mathrm{H}, 5.2,13.2 \mathrm{~Hz}), 2.99-3.02(\mathrm{dd}, 1 \mathrm{H}, 10.0$, 13.2Hz), 3.08-3.14 (dd, $1 \mathrm{H}, 10.4,13.2 \mathrm{~Hz}), 3.20-3.25(\mathrm{~m}, 1 \mathrm{H}), 3.37-3.41(\mathrm{dd}, 1 \mathrm{H}, 2.8$, 13.2Hz), 3.82, (s, 3H), $6.26(\mathrm{~d}, 1 \mathrm{H}, 1 \mathrm{~Hz}), 6.91-6.93(\mathrm{dd}, 2 \mathrm{H}, 2.2,3.1 \mathrm{~Hz}), 7.36-7.41(\mathrm{dd}$, $4 \mathrm{H}, 8.8,11.4 \mathrm{~Hz}), 7.55-7.61(\mathrm{dd}, 4 \mathrm{H}, 8.8,12.8 \mathrm{~Hz}), 7.78-7.80(\mathrm{dd}, 2 \mathrm{H}, 2,6.8 \mathrm{~Hz}) ;{ }^{13} \mathrm{C}$ NMR $\delta 202.8,172.5,162.5,161.5,152.4,149.5,137.7,137.1,133.3,129.6,129.6,129.5$, 128.7, 128.5, 128.4, 121.0, 114.6, 99.4, 55.6, 45.2, 31.1, 30.9. ESI MS (M+H) m/z calcd, 517.10; found, 518.12. HRMS (ESI) for $\mathrm{C}_{28} \mathrm{H}_{22} \mathrm{Cl}_{2} \mathrm{~N}_{3} \mathrm{O}_{3}$ calcd $518.1033\left(\mathrm{M}+\mathrm{H}^{+}\right)$, obsd 518.1008 .

\section{3,8-Bis-(4-bromophenyl)-6-[3-(4-methoxyphenyl)-isoxazol-5-yl]-6,7-dihydro-5H-}

[1,2]diazocin-4-one (1g). Following the general 1,2 diazocinone synthesis cyclobutanone 3b and tetrazine 2c gave 1g (42mg, 30\%): IR (neat) 1713, 1611, 1429, $1251 ;{ }^{1} \mathrm{H}$ NMR $\delta$ 2.84-2.90 (dd, $\left.1 \mathrm{H}, 5.2,12.4 \mathrm{~Hz}\right), 3.02-3.10$ (dd, $\left.1 \mathrm{H}, 10.2,12.7 \mathrm{~Hz}\right), 3.14-$ $3.22(\mathrm{dd}, 1 \mathrm{H}, 10.7,12.9 \mathrm{~Hz}), 3.25-3.29(\mathrm{~m}, 1 \mathrm{H}), 3.45-3.51(\mathrm{dd}, 1 \mathrm{H}, 2.2,12.1 \mathrm{~Hz}), 3.85(\mathrm{~s}$, $3 \mathrm{H}), 6.32(\mathrm{~s}, 1 \mathrm{H}), 6.94-7.01(\mathrm{dd}, 2 \mathrm{H}, 1.9,6.6), 7.42-7.47(\mathrm{~m}, 4 \mathrm{H}), 7.63-7.70(\mathrm{~m}, 4 \mathrm{H})$, 7.88-7.91 (m, 2H); ${ }^{13} \mathrm{C} \delta 29.7,30.7,30.8,44.9,99.5,126.7,128.4,128.7,128.0,139.72$, 130.4, 132.2, 132.3, 133.4, 149.3, 152.2, 162.3, 172.5, 202.4. ESI MS $(\mathrm{M}+\mathrm{H}) \mathrm{m} / \mathrm{z}$ calcd, 604.99; found, 605.87. HRMS (ESI) for $\mathrm{C}_{28} \mathrm{H}_{22} \mathrm{Br}_{2} \mathrm{~N}_{3} \mathrm{O}_{3}$ calcd 606.0022 $\left(\mathrm{M}+\mathrm{H}^{+}\right)$, obsd 605.9992.

8-(4-Methoxyphenyl)-3-p-tolyl-6-(3-p-tolylisoxazol-5-yl)-6,7-dihydro-5H-

[1,2]diazocin-4-one (1h). Following the general 1,2 diazocinone synthesis 
cyclobutanone $\mathbf{3 b}$ and tetrazine $\mathbf{2 d}$ gave $\mathbf{1 h}(43 \mathrm{mg}, 36 \%)$ : IR (neat) 1613, 1430, 1250; ${ }^{1} \mathrm{H}$ NMR $\delta 2.36(\mathrm{~s}, 1 \mathrm{H}), 2.39(\mathrm{~s}, 1 \mathrm{H}), 2.80-2.85(\mathrm{dd}, 1 \mathrm{H}, J=5.1,12.6 \mathrm{~Hz}), 2.80-3.06(\mathrm{dd}, 1 \mathrm{H}$, $10.4,12.6 \mathrm{~Hz}), 3.12-3.18(\mathrm{dd}, 1 \mathrm{H}, J=10.8,13.18 \mathrm{~Hz}), 3.22-3.27(\mathrm{~m}, 1 \mathrm{H}), 3.40-3.44(\mathrm{dd}$, $1 \mathrm{H}, 2.0,13.0 \mathrm{~Hz}) 3.84(\mathrm{~s}, 3 \mathrm{H}), 6.27-6.28(\mathrm{~d}, 1 \mathrm{H}, 1 \mathrm{~Hz}), 6.93-6.95(\mathrm{dd}, 2 \mathrm{H}, 2.2,6.9 \mathrm{~Hz})$ 7.21-7.25 (m, 4H), 7.54-7.55 (dd, 2H, 1.5,6.4Hz), 7.62-7.64 (dd, 2H, 2.0, 4.2Hz), 7.75$7.77(\mathrm{~d}, 2 \mathrm{H}, 8.2 \mathrm{~Hz}) ;{ }^{13} \mathrm{C} \delta 204.3,173.3,162.5,161.5,153.9,150.6,141.9,141.2,132.4$, 130.1, 129.9, 128.6, 128.5, 127.5, 127.2, 121.3, 114.7, 99.3, 55.7, 45.3, 31.3, 31.2, 21.8, 21.7. ESI MS (M+H) $\mathrm{m} / \mathrm{z}$ calcd, 477.21; found, 478.16. HRMS (ESI) for $\mathrm{C}_{30} \mathrm{H}_{28} \mathrm{~N}_{3} \mathrm{O}_{3}$ calcd 478.2125 $\left(\mathrm{M}+\mathrm{H}^{+}\right)$, obsd 478.2136. 


\section{Detailed Spectroscopic and HPLC Data for compounds 1a-h}

1a:
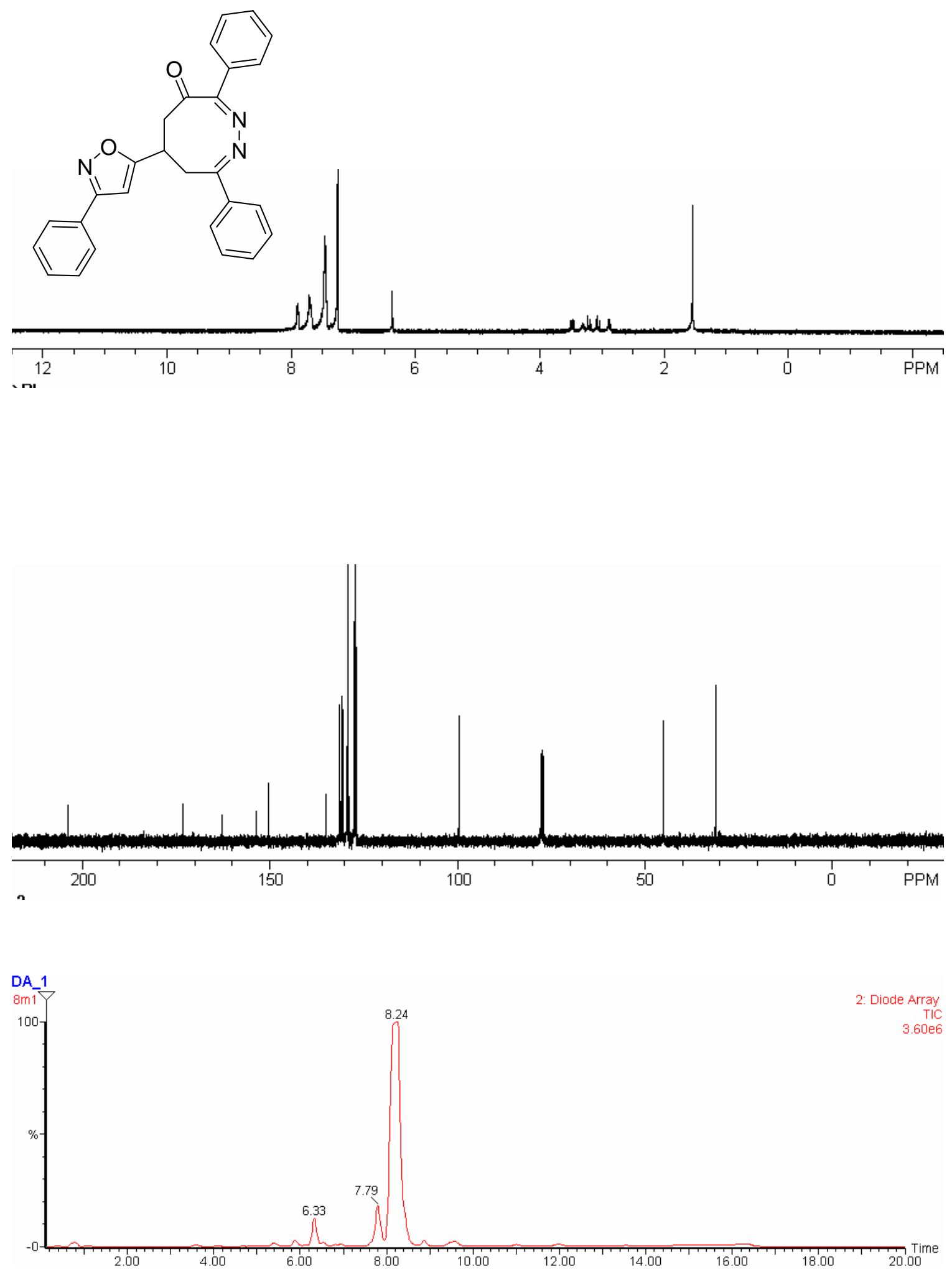

Page S10 

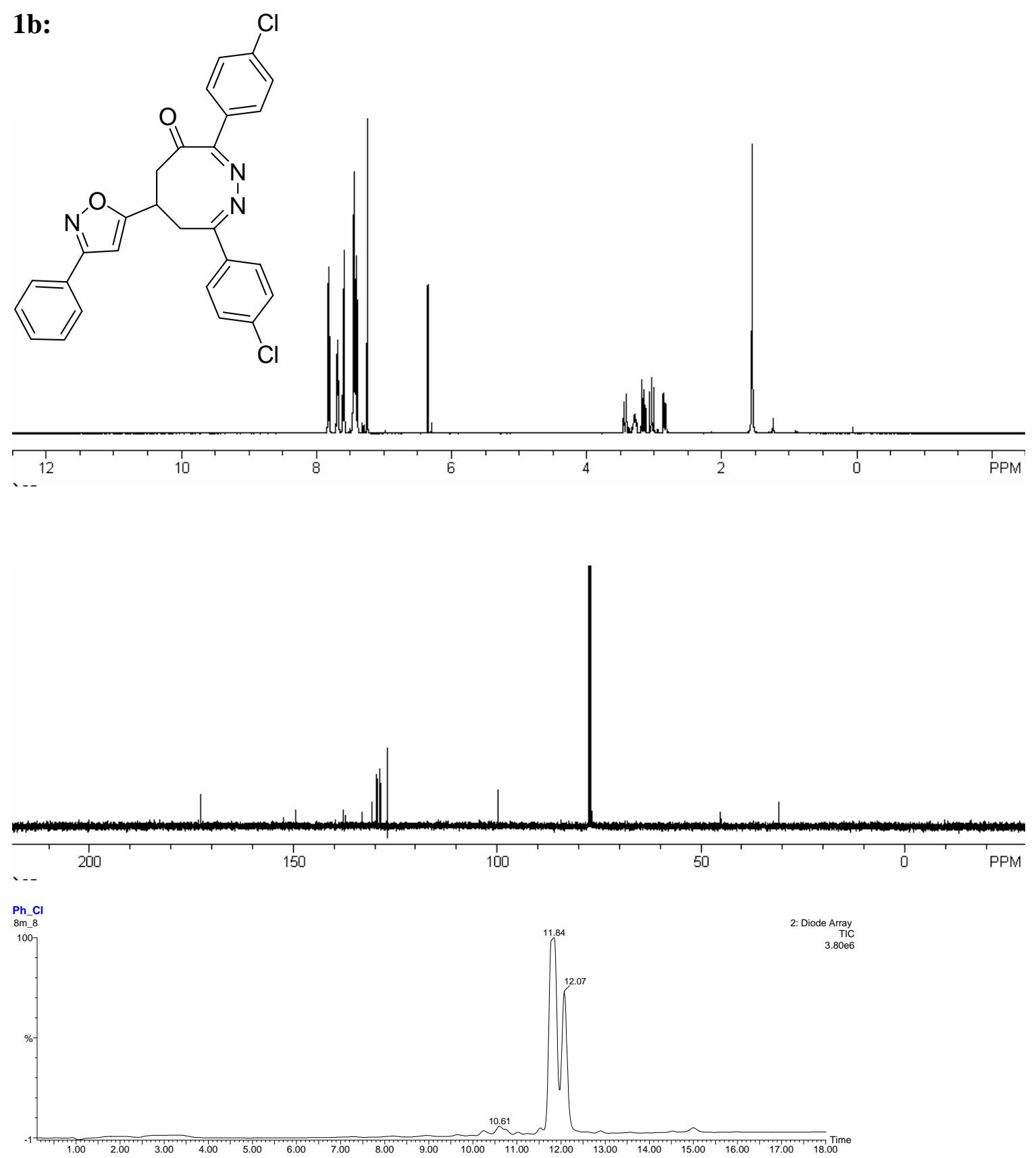

Page S11 
1e:
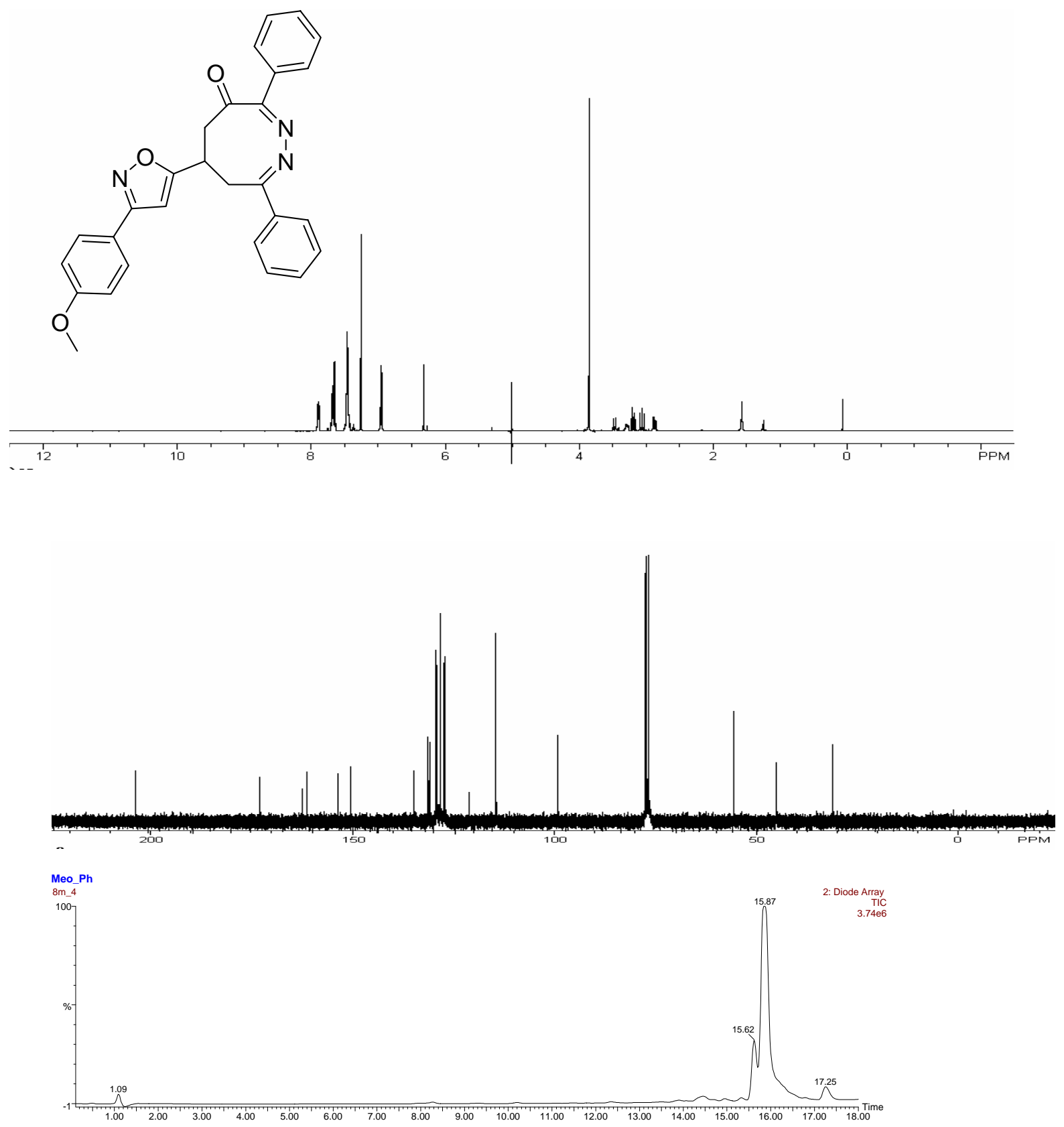

Page S12 

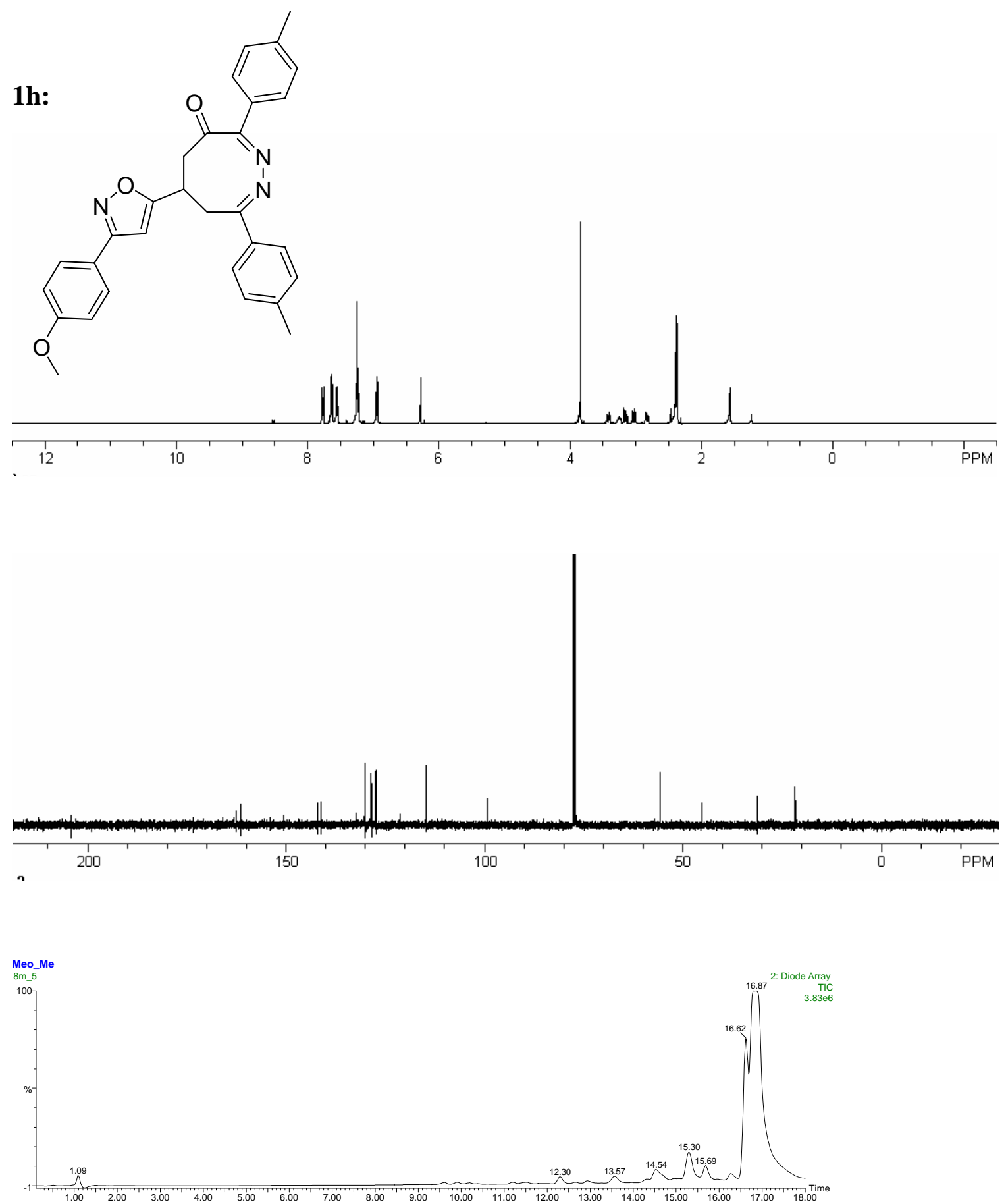

Page S13 
1c:
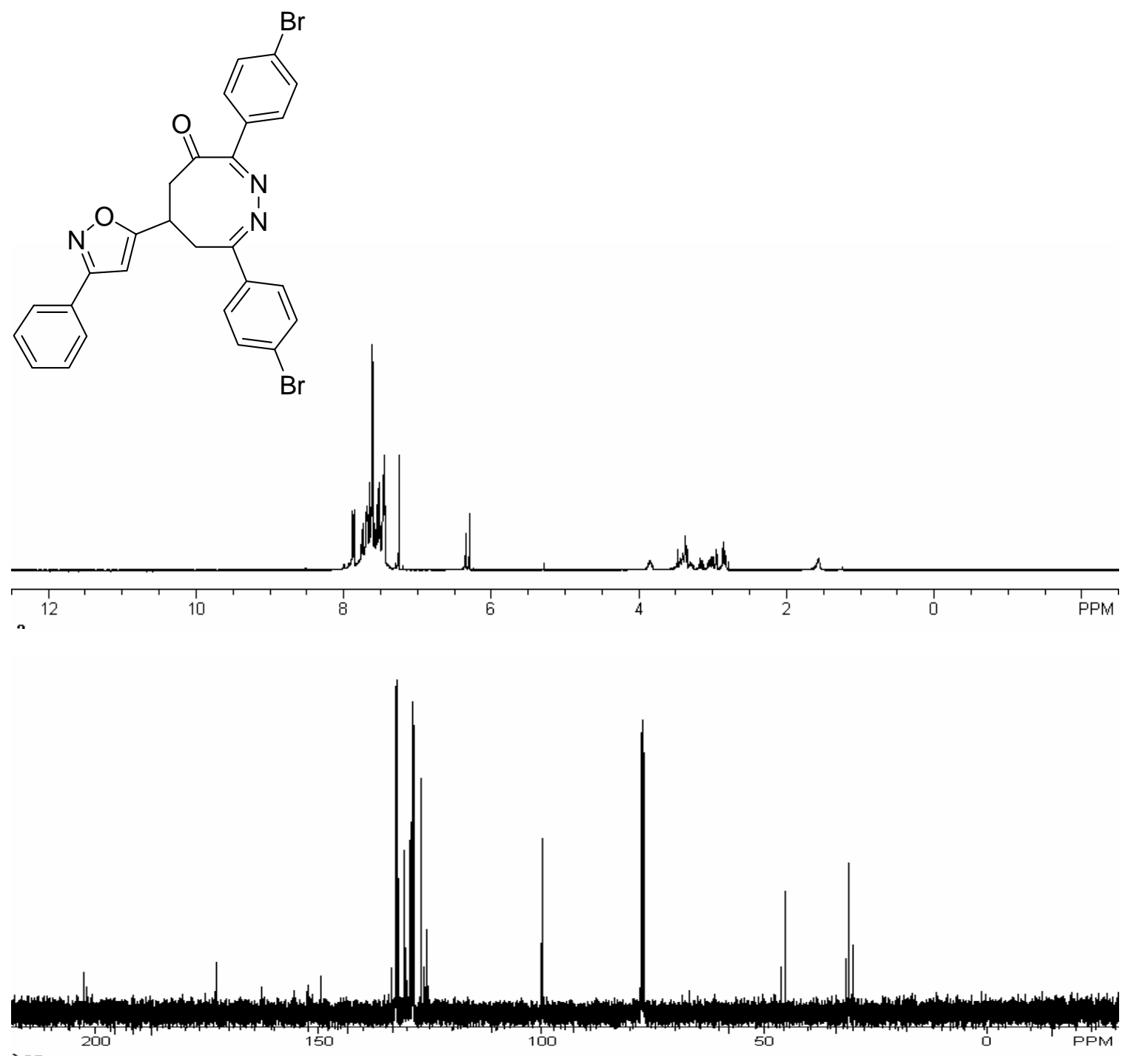

Ph_Br

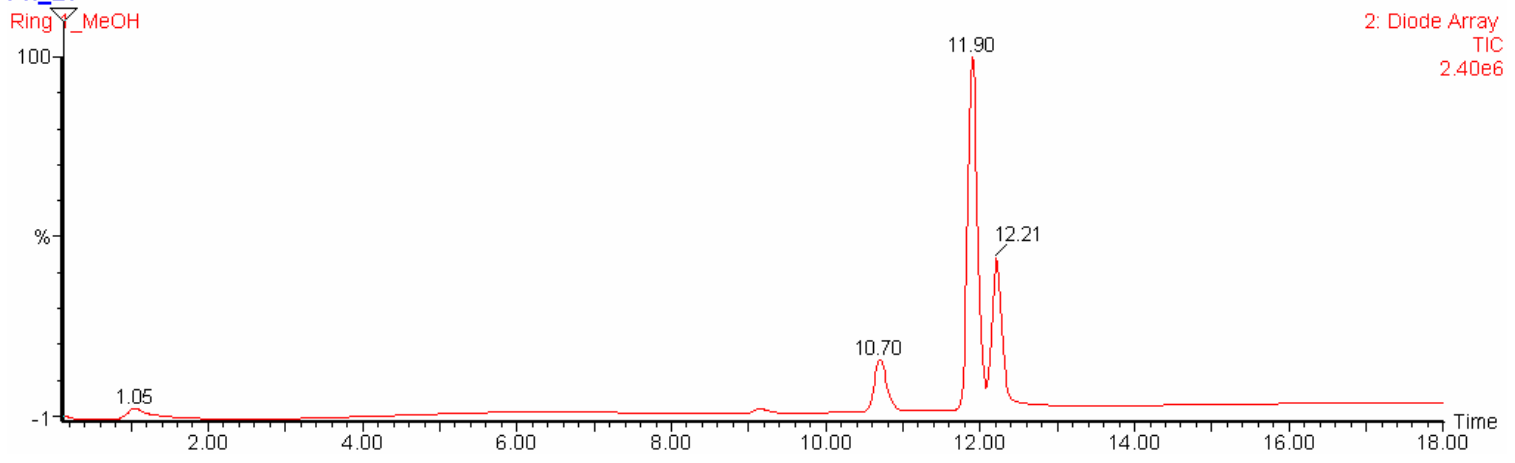

Page S14 
1f:
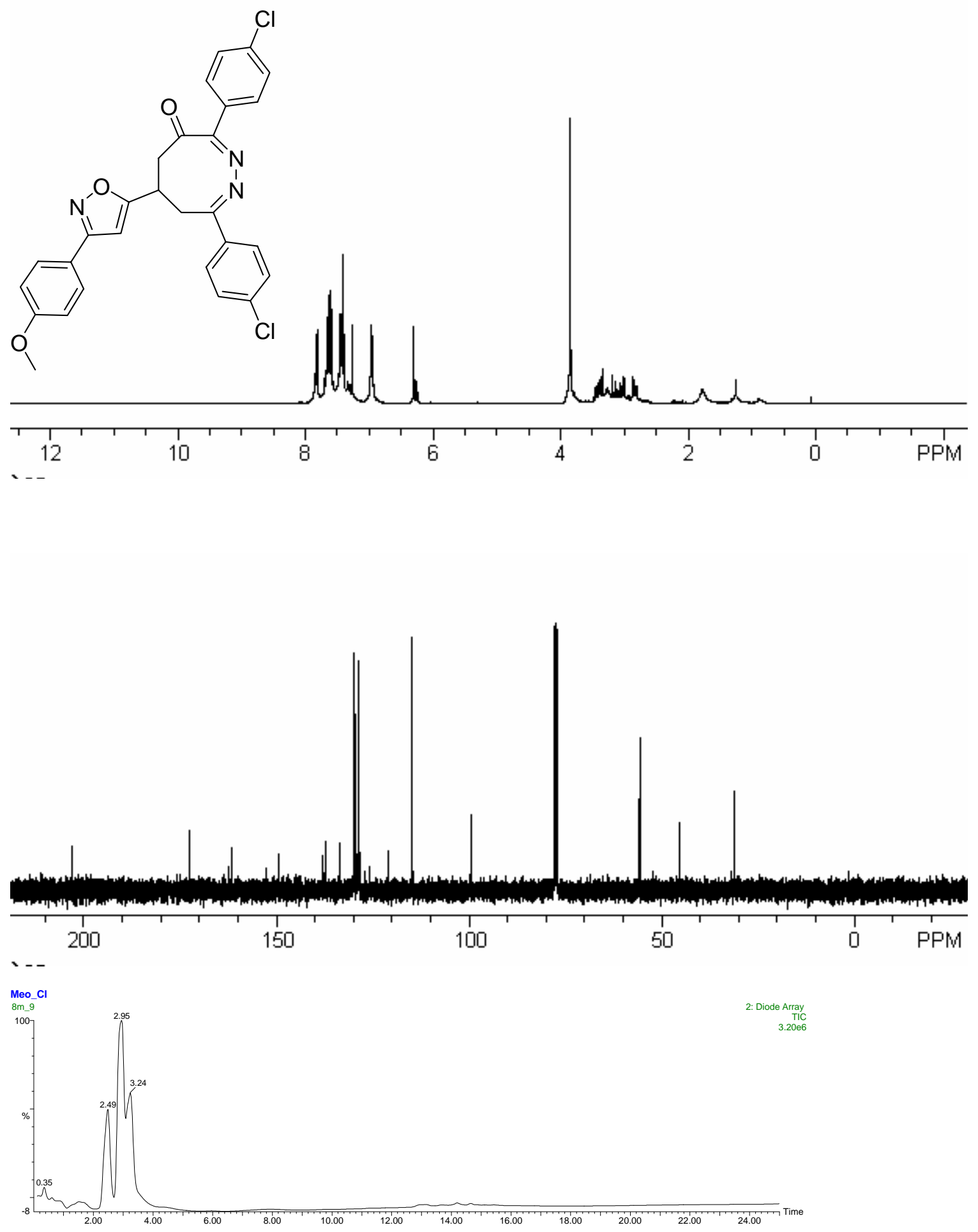

Page S15 
1d:
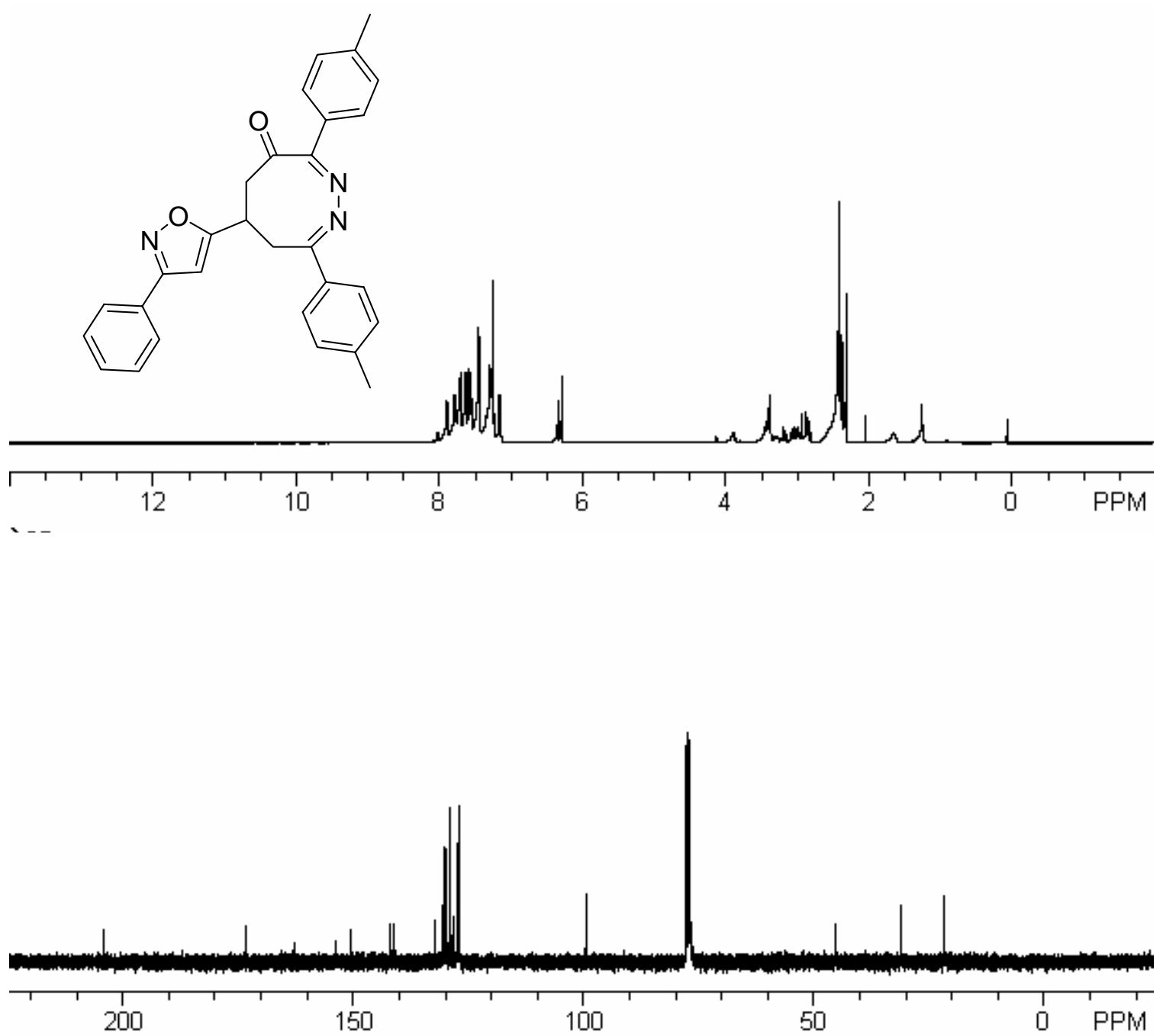

$=-$

$\mathrm{Ph} \_\mathrm{Br}$
Ring 1_MeOH

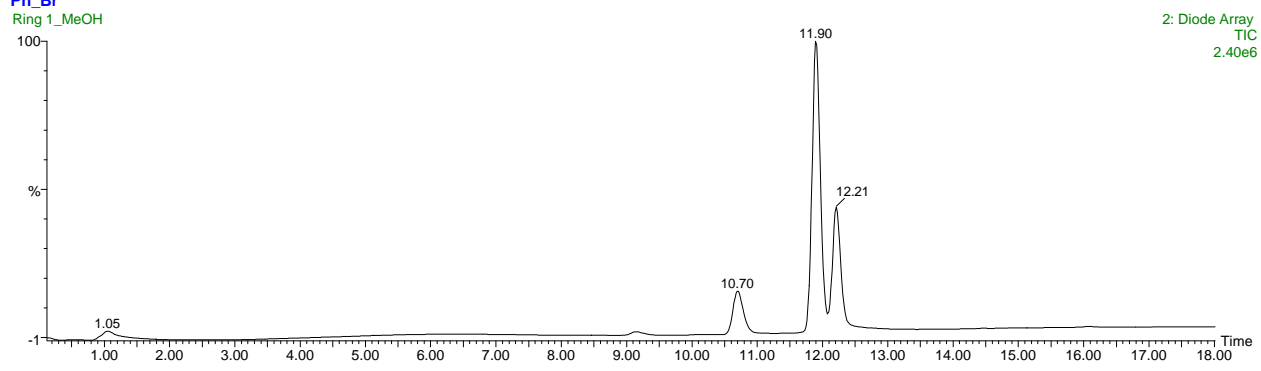

Page S16 

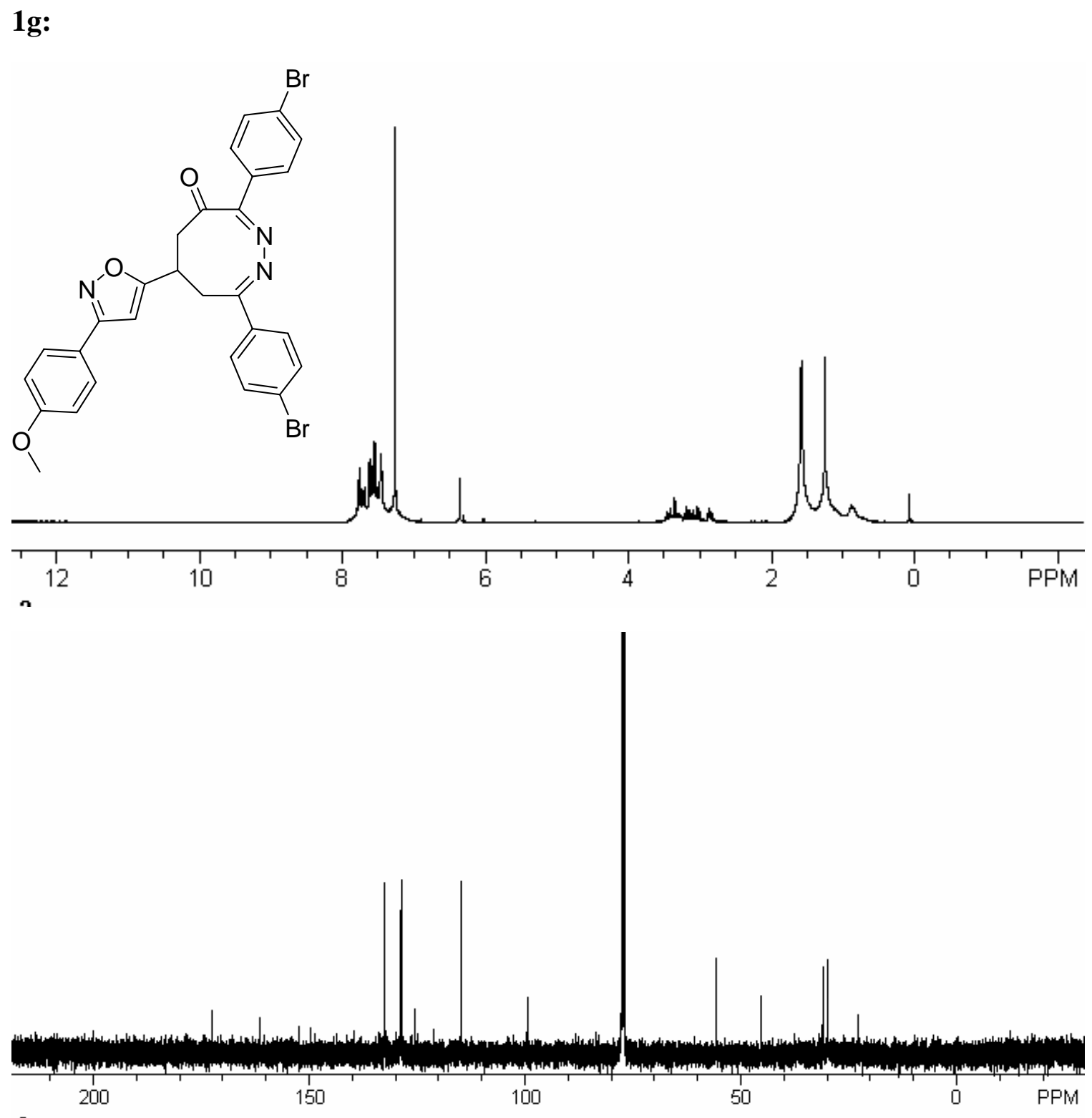

n

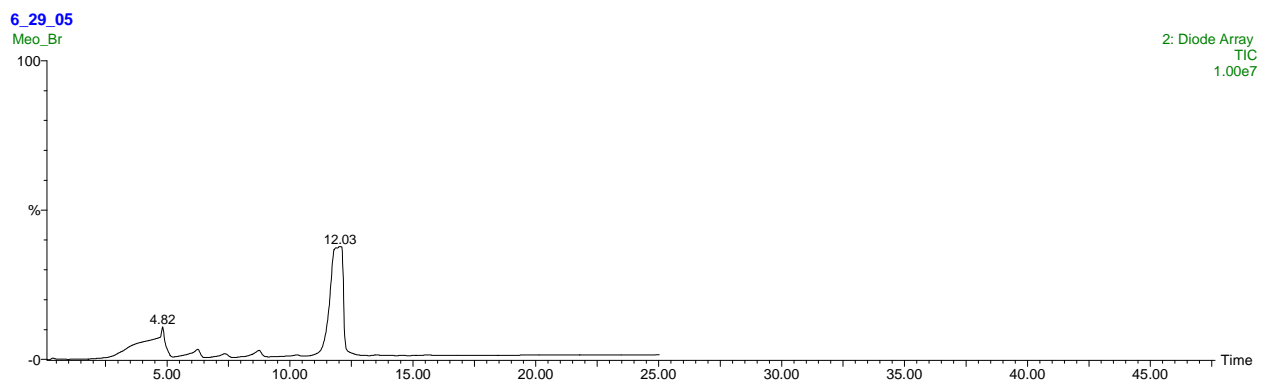

Page S17 
Detailed Spectroscopic and HPLC data for 3a and 10a:

3a:
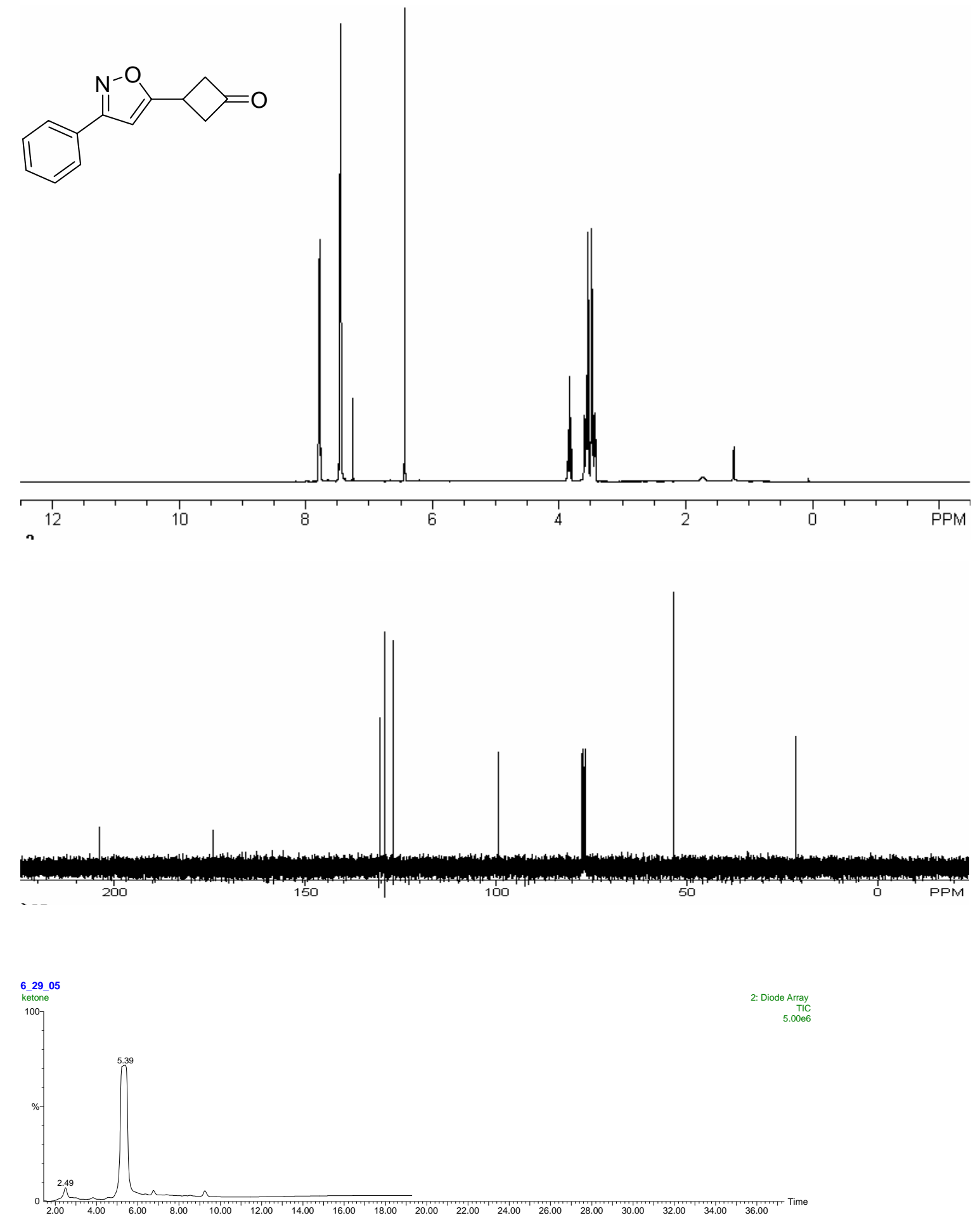

Page S18 

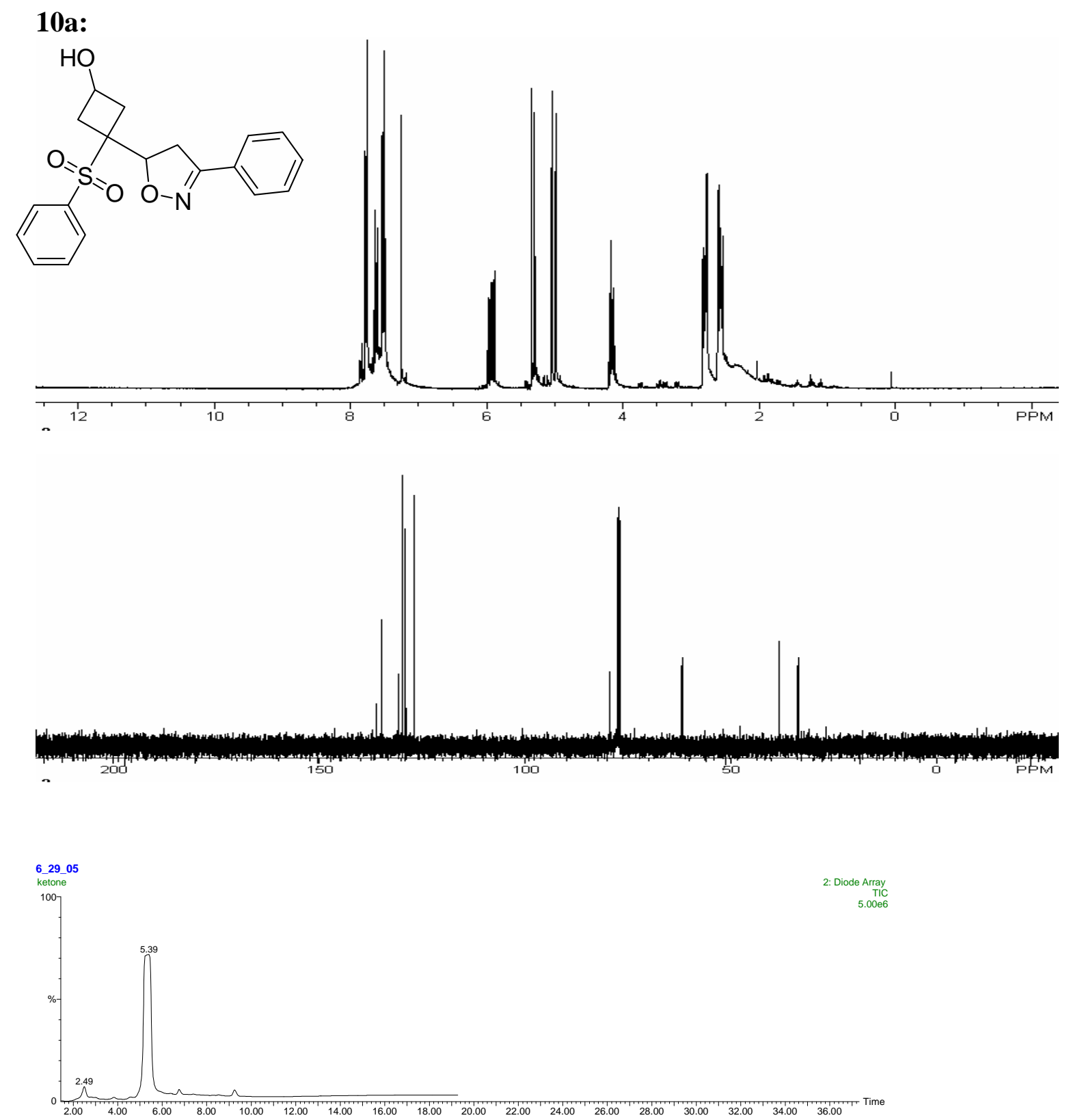

Page S19 
X-ray Crystallography. A colorless needle, obtained by recrystallization from acetonitrile, with approximate orthogonal dimensions $0.49 \times 0.04 \times 0.04 \mathrm{~mm}^{3}$ was placed and optically centered on the Bruker SMART APEX CCD system at $-183^{\circ} \mathrm{C}$. The initial unit cell was indexed using a least-squares analysis of a random set of reflections collected from three series of $0.3^{\circ}$ wide $\omega$-scans, 10 s per frame, and 20 frames per series that were well distributed in reciprocal space. Four $\omega$-scan data frame series were collected $[\mathrm{MoK} \alpha]$ with $0.3^{\circ}$ wide scans, $20 \mathrm{~s}$ per frame and 606 frames collected respectively per series at varying $\varphi$ angles $\left(\varphi=0^{\circ}, 90^{\circ}, 180^{\circ}, 270^{\circ}\right)$. The crystal to detector distance was $4.97 \mathrm{~cm}$, thus providing a complete sphere of data to $2 \theta_{\max }=60.21^{\circ}$. A total of 66702 reflections were collected and corrected for Lorentz and polarization effects and absorption using Blessing's method as incorporated into the program $\mathrm{SADABS}^{2}$ with 13768 unique. All crystallographic calculations were performed on a Personal computer (PC) with a Pentium $3.20 \mathrm{GHz}$ processor and $1 \mathrm{~GB}$ of extended memory. The SHELXTL ${ }^{3}$ program package was implemented to determine the probable space group: noncentrosymmetric orthorhombic space group Pna2 $2_{1}$ (no. 33) or the centrosymmetric orthorhombic space group Pnma (no. 62). The structure was determined by direct methods with the successful location of a majority of two equivalent molecules comprising the asymmetric unit using the program $\mathrm{XS}^{4}$ in $\mathrm{Pna}_{1}$ and refined with $\mathrm{XL}^{4}$ The 66702 data collected were merged based upon identical indices yielding 47712 data $[\mathrm{R}(\mathrm{int})=0.0488]$ that were truncated to $2 \theta_{\max }=60.00^{\circ}$ resulting in 44559 data that were further merged during least-squares refinement to 12184 unique data $[R(i n t)=0.0795]$. A single least-squares difference-Fourier cycle was required to locate the remaining nonhydrogen atoms. All non-hydrogen atoms were refined anisotropically. Hydrogen atoms 
were initially placed in calculated positions but then allowed to refine freely during the final convergence stages. The final structure was refined to convergence $[\Delta / \sigma \leq 0.001]$ with $\mathrm{R}(\mathrm{F})=7.02 \%$, $w \mathrm{R}\left(\mathrm{F}^{2}\right)=11.61 \%, \mathrm{GOF}=1.011$ for all 12184 unique reflections $\left[R(F)=4.96 \%\right.$, wR $\left(F^{2}\right)=10.72 \%$ for those 9616 data with $\left.F o>4 \sigma(F o)\right]$. The final difference-Fourier map was featureless indicating that the structure is both correct and complete. The absolute structure parameter, Flack (x), ${ }^{5}$ was found to be $0.1(9)$ indicating that the correct enantiomorph cannot be chosen with certainty based upon the atoms present. The function minimized during the full-matrix least-squares refinement was $\Sigma \mathrm{w}\left(\mathrm{Fo}^{2}-\mathrm{Fc}^{2}\right)$ where $\mathrm{w}=1 /\left[\sigma^{2}\left(\mathrm{Fo}^{2}\right)+(0.0384 * \mathrm{P})^{2}+2.9926 * \mathrm{P}\right]$ and $\mathrm{P}=\left(\max \left(\mathrm{Fo}^{2}, 0\right)+\right.$ $\left.2 * \mathrm{Fc}^{2}\right) / 3$. An empirical correction for extinction was also attempted but found to be negative and therefore not applied.

Electronic Structure Calculations. All reported electronic structure calculations were carried out with Gaussian $03{ }^{6}$ Geometry optimizations and harmonic frequency calculations of the TB, TBC and TS structures were performed at the B3LYP/6-31G(d) level. ${ }^{7}$ TS was optimized using the STQN ${ }^{8}$ method and showed only one imaginary frequency. IRC ${ }^{9}$ calculations confirmed that TS connected the TB and TBC conformers. The final single-point energies of the optimized geometries were calculated at the B3LYP/6-311+G(2d,p) level. Zero-point energies from the frequency analyses at the B3LYP/6-31G(d) level (scaled by 0.9806$)^{10}$ are included in the reported relative energies. NMR coupling constants for $\mathrm{TB}$ and $\mathrm{TBC}$ were calculated using the $\mathrm{GIAO}^{11}$ method implemented into Gaussian 03 at the B3LYP/6-311+G(2d,p) level using the B3LYP/6-31G(d) optimized geometries. 


\section{References}

(a) Cheng, W-C.; Wong, M.; Olmstead, M. M.; Kurth, M. J. Organic Let. 2002, 4, 741. (b) Cheng, W-C.; Olmstead, M. M.; Kurth, M. J. J. Org. Chem. 2001, 66, 5528. (c) Cheng, W-C.; Halm, C.; Evarts, J. B.; Olmstead, M. M.; and Kurth, M. J. J. Org. Chem. 1999, 64, 8557. (d) Halm, C.; Kurth, M. J. Tetrahedron Lett. 1997, 38, 7709.

2 (a) Blessing, R. H. Acta Cryst. 1995, A51, 33-38. (b) Sheldrick, G.M., SADABS (2003) Version 2.10, 'Siemens Area Detector Absorption Correction' Universität Göttingen: Göttingen, Germany.

3 Sheldrick, G.M., (2002). SHELXTL. Version 6.1. Bruker AXS Inc., Madison, Wisconsin, USA.

4 Sheldrick, G. M., (1997). SHELXS97 and SHELXL97. Universität Göttingen: Göttingen, Germany.

$5 \quad$ Flack, H. D. Acta Cryst. 1983, A39, 876-881

6 Gaussian 03, Revision B.04, Frisch, M. J.; Trucks, G. W.; Schlegel, H. B.; Scuseria, G. E.; Robb, M. A.; Cheeseman, J. R.; Montgomery, Jr., J. A.; Vreven, T.; Kudin, K. N.; Burant, J. C.; Millam, J. M.; Iyengar, S. S.; Tomasi, J.; Barone, V.; Mennucci, B.; Cossi, M.; Scalmani, G.; Rega, N.; Petersson, G. A.; Nakatsuji, H.; Hada, M.; Ehara, M.; Toyota, K.; Fukuda, R.; Hasegawa, J.; Ishida, M.; Nakajima, T.; Honda, Y.; Kitao, O.; Nakai, H.; Klene, M.; Li, X.; Knox, J. E.; Hratchian, H. P.; Cross, J. B.; Bakken, V.; Adamo, C.; Jaramillo, J.; Gomperts, R.; Stratmann, R. E.; Yazyev, O.; Austin, A. J.; Cammi, R.; Pomelli, C.; Ochterski, J. W.; Ayala, P. Y.; Morokuma, K.; 
Voth, G. A.; Salvador, P.; Dannenberg, J. J.; Zakrzewski, V. G.; Dapprich, S.; Daniels, A. D.; Strain, M. C.; Farkas, O.; Malick, D. K.; Rabuck, A. D.; Raghavachari, K.; Foresman, J. B.; Ortiz, J. V.; Cui, Q.; Baboul, A. G.; Clifford, S.; Cioslowski, J.; Stefanov, B. B.; Liu, G.; Liashenko, A.; Piskorz, P.; Komaromi, I.; Martin, R. L.; Fox, D. J.; Keith, T.; Al-Laham, M. A.; Peng, C. Y.; Nanayakkara, A.; Challacombe, M.; Gill, P. M. W.; Johnson, B.; Chen, W.; Wong, M. W.; Gonzalez, C.; and Pople, J. A.; Gaussian, Inc., Wallingford CT, 2004.

7 (a) Stephens, P. J.; Devlin, F. J.; Chabalowski, C. F.; Frisch, M. J. J. Phys. Chem. 1994, 98, 11623-11627. (b) Becke, A. D. J. Chem Phys. 1993, 98 5648-5652. (c) Becke, A. D. J. Chem Phys. 1993, 98 1372-1377. (d) Lee, C.; Yang, W.; Parr, R. G. Phys. Rev. B. 1988, 37, 785-789.

8 (a) Peng, C; Ayala, P. Y.; Schlegel, H. B.; Frisch, M. J. J. Comp. Chem. 1996, 17, 49-56. (b) Peng, C; Schlegel, H. B. Israel J. Chem. 1994, 33, 449-454.

9 (a) Gonzalez, C., Schlegel, H. B. J. Phys. Chem. 1990, 94, 5523-5527. (b) Gonzalez, C., Schlegel, H. B. J. Chem. Phys. 1989, 90, 2154-2161.

10 Scott, A. P.; Radom, L. J. Phys. Chem. 1996, 100, 16502-16513.

11 (a) Cheeseman, J. R.; Trucks, G. W.; Keith, T. A.; Frisch, M. J. J. Chem. Phys. 1996, 104, 5497-5509. (b) Wolinski, K.; Hinton, J. F.; Pulay, P. J. Am. Chem. Soc. 1990, 112, 8251-8260. (c) Ditchfield, R. Mol. Phys. 1974, 27, 789-807. 